\title{
One Teaspoon at a Time: Saving a Company by Engaging the Community
}

\author{
Mary Catherine Colley ${ }^{1}$ \\ ${ }^{1}$ Department of Marketing, Sorrell College of Business, Troy University, Troy, AL, USA \\ Correspondence: Mary Catherine Colley, Department of Marketing, Troy University, Troy, AL 36082, USA. Tel: \\ 1-334-448-5166. E-mail: mccolley@troy.edu
}

Received: October 15, 2014

Accepted: November 10, 2014 Online Published: November 26, 2014

doi:10.5539/jms.v4n4p70

URL: http://dx.doi.org/10.5539/jms.v4n4p70

\begin{abstract}
How does a grease recycling program pull a community together and help put a local utility company back in the black...or green? In 2005 a new manager was hired to manage risk and reputation, as well as increase profitability of a water utility company. While accomplishing that, the GM wished to improve the attitude, management, and branding of a utility company which had lost five million dollars over the course of 12 years. Several improvements and changes took place under new management. One of the many transformed areas was sewage spills. One sewage spill can cost tens of thousands of dollars to clean up. A $\$ 12,000$ grease recycling program helped reduce the company costs through fewer sewage spills. The general manager used the program as an opportunity engage and bond with the community. Communication was the key and the General Manager had found a story about a teaspoon of grease that could be told in different ways to relate to and educate all age groups in the community. In the end, the company helped to successfully engage the community which improved the company's worker morale, reputation, image, brand, and profitability.
\end{abstract}

Keywords: sustainability, water management, branding

\section{Introduction}

Daphne Utilities services the local community in Daphne, AL by providing water, sewer, and natural gas services. It is a small town of approximately 24,000 people. It covers less than 18 square miles and includes approximately 10,000 houses (United State Census Bureau, 2013).

\subsection{The Problem Statement}

Daphne Utilities lost five million dollars from 1993 to 2005. In 2005 a new manager was hired to make the utility profitable. Overall, "the utility struggled to meet the basic needs of the town's water demand and the company was on the verge of financial ruin." (McElroy, 2011a) In addition, there were other problems to consider before crafting a strategy, such as:

- Management: There was a splintered workforce and low morale which led to tardiness and many absences.

- Financial: The utility was near bankruptcy.

- Operational: The utility was not able to meet water demands of customers, and there were wastewater treatment plant technical issues but no money to fund solutions. (McElroy, 2011c).

To turn a profit and successfully manage the workforce, finances, and operations, the GM realized he needed to improve worker attitude, management, and branding which he believed the key to improving the overall operations of the company. He approached this challenge by crafting a strategy to improve the utility's image through a branding strategy that engaged and educated the community. This strategy was needed to improve the poor image of the company as it had little connection with the community.

The overarching theme was to manage risk and improve the utility's reputation, believing that doing so would basically improve the management, financial and operational concerns. This approach included a sustainable business strategy that would involve the community and the workforce.

\subsection{Sewer spills}

One aspect that contributed to this poor image was sewage spills. A sewage spill is an overflow of untreated or 
partially treated sewage from the sewer system. Sewage can flow from manholes, open cleanout lines, or toilets and drains in your home and can cause health hazards, damage homes and businesses and threaten the environment as well as local waterways and beaches (Preventing Sewage Spills, n.d.). Among roots and cracks in or faulty sewer lines, fats, oil, and grease (FOG) is one of the leading causes of sewer spills (Pollution Prevention Project: Sewage Spill Reference, n.d.).

With Daphne, AL situated near Mobile Bay any type of sewer spillage could contaminate the bay. "In addition to the adverse environmental impact, there is also the enormous cost to the utility, both in actual cost in manpower and materials to clean up but also time spent completing reports for the Alabama Department of Environmental Management. Preventing sewer spills can be time that the workforce can spend on other valuable areas. In addition, if the utility company is always cleaning up sewer spills and is visible in the community, it does not shed a positive light on the utility's reputation" ("Cease the Grease", n.d.).

Although the utility made a profit from cleaning up sewage spills, it did not create a positive image of a company trying to improve its community. Cleaning up sewage spills was reactionary and the utility realized they should be more proactive in preventing sewage spills. In addition, because of its close proximity to the bay and gulf, preservation of the water is even more important to consider when there are sewage spills.

When a sewage spill happens and meets certain criteria set forth by the environmental agency, they are to be reported to the Alabama Department of Environmental Management, the mayor's office, and the media. This results in a reputational and managerial risk to the utility company. Even though Daphne, AL rarely experienced sewage spills that met the criteria set forth, any sewage spill impacted the reputation of utility company. Daphne Utilities "defines the term 'spill' more broadly to include any overflow or near overflow condition that causes the utility to dispatch clean-up crews and basically work to keep any reportable spill from occurring. Broadly speaking, a spill to us is something that makes us spend money to clean up and protect from a potentially reportable sewer spill" ("Cease the Grease", n.d.).

\section{The Solution}

To help reduce the number of sewer spills and save money being spent on cleanup, the manager implemented a grease recycling program and created a story to help sell the idea. It created a chain reaction effect which helped improve several problem areas: reputation, image, worker morale, branding, risk, and profitability. The grease recycling program was an inexpensive but effective way to reduce costs and manage risk while building a relationship between the community and the utility workforce. It turned out to be a simple, but effective sustainable solution.

\subsection{Education}

The utility began educating the community on how to reduce residential sewer spillage, much of which could be accomplished by not pouring grease down the drain in your own home. Engaging the community helped the workforce connect what they were doing to how it improved the lives of the people in the community. Less grease being poured down the drain reduced the amount of residential sewage spills, which reduced the amount of time that the utility workforce spent cleaning up spills, which meant less money was being spent to clean up the residential sewage spills. While the utility company can clean up the spills, it is the actual homeowners who are the ones who can help to prevent them from happening.

The overarching goal was to manage risk and improve the utility's reputation, believing that doing so would basically improve the management, financial, and operational concerns. The desired end result was to improve the bottom line that encompassed Elkington's (1994) triple bottom line accounting approach which includes the three dimensions of performance: environment, financial, and social. For Daphne Utilities this meant the community (social), water (environment), and the financial (profits).

\subsection{Sustainable business strategy}

How the General Manager accomplished this can be related back to Urlaub (2013) where she outlined in her book how to implement a sustainable business strategy to manage risk as a business opportunity. She used the following: 1) Define the value, 2) Bridge the gap, 3) Speak the business language, 4) Bridge up, and 5) Who's at the table. Below is a summary of the how Daphne Utility's strategic success is related to Urlaub's process:

\section{Define the value}

Urlaub (2013) states that "each organization identifies value differently. Thus her question is "What is the company's perspective on value?" Kotler (2012) defines value as "the right combination of quality, service and price." The GM had to precisely identify what is of value to the utility company and what value does the 
company want to provide to the community? Evaluation of these questions was needed to determine how focusing on those values can ultimately provide bottom line impact to Daphne Utilities. Their mission statement clearly states what it values.

"Daphne Utilities is committed to providing uninterrupted water, sewer and natural gas utility services that set the Standard of Excellence by which other utilities are compared. Meeting the needs of our customers by delivering exceptional service in a professional and friendly manner at the lowest possible cost. Supporting the growth of the Daphne community by providing environmental sound and cost effective utility services to the City and developing areas. Providing our Employees with a rewarding work experience that promotes teamwork, professionalism, growth and excellence in performance" ("About Daphne Utilities" n.d.).

Daphne Utilities' mission statement consists of four key pillars: provide uninterrupted utility service, meet customer needs with exceptional customer service at the lowest cost possible, support the growth of the community, and provide a rewarding work experience. Their mission statement provides an opportunity for the utility company to achieve their business objectives using sustainable practices.

Now the GM had to determine how to deliver the value and turn a profit. He had defined the value through the mission statement, now the goal was to determine the best way to communicate and deliver it. If value ultimately depends on the perceiver, then his challenge was also to change the perception of the utility's stakeholders.

Bridge the Gap

Urlaub's (2013) second step in creating a sustainable business strategy is to "connect the dots from the current status to the vision by helping those to capture their own vision and define a path forward to live in it." The value is defined. Now Daphne Utilities needs to turn those values into a strategy to move forward.

The GM needed to make a connection with the community in order to help reach the goals he set out to accomplish. He needed the customer's (the community's) help in making Daphne Utilities a profitable company. It would not be a one-time call for help. The GM needed to find a way to continuously engage the community with the utility workforce and communicate to them, that with their efforts, the utility could become a success. He had to determine what would work best to engage the community and get them involved in making their community a better place to live. He had the idea. He just had to convey the message convincingly to the community.

The grease recycling program created that opportunity, but just making a grease recycling program available is not enough. The GM was constantly out in the community and at council meetings touting the importance of what they were trying to do by saying "By keeping our sewers clean, the planet stays clean." The GM realized that everyone could rally around that goal. "Seminars were offered to the local public and meetings with local restaurant managers were held to teach local companies about their part in managing sewer spills. Educational programs were taken into the local school and adjusted to their level of understanding and involvement potential. For example, they would tell the children "When your mother is cooking that fried chicken or French fries, be sure to tell her not to pour that old oil down a drain or toilet." ("Cease the Grease", n.d.)

\section{Speak the business language}

Urlaub's (2013) third item in the process is "Tie business objectives to sustainability. What gets measured gets managed. Hence, identify key metrics and tie to the bottom line." It is not difficult for a water utility to tie company values and business objectives to sustainability. Water is one of our scarcest resources and everyone has a responsibility to be diligent in using it effectively.

Daphne Utilities had to determine how to convey effectively to their customers, employees, and stakeholders how efforts to implement sustainability (thus managing risk) would impact and improve the triple bottom line. The company lost money for 12 years and they knew they needed to regain the trust and confidence of the community to help turn around the utility.

The GM wanted to "improve the utility's image and build support for the utility so as to show the value of the company to the community." (McElroy, 2011a) Part of the poor company image could be traced back to the community seeing the utility workers in the community cleaning up sewer spills. Nobody wants a sewer spill to happen as it costs time and money to repair. It also damages the environment and is an eyesore. While it is part of the utility worker's job to clean up spills, that time could be put to better use by educating the community on how to prevent sewer spills so worker efforts could be spent on other areas that would be more productive and aligned to the purpose of the utility. 


\section{Bridge up}

While the company was interested in sustaining itself financially, the nature of the business allowed the company to also use the goal of reducing sewer spills to reduce the negative environmental impact and create a better image for the utility. Urlaub's (2013) fourth step asks "What existing programs wrap up the overarching sustainability plan?" As there were no existing programs in place to reduce sewer spills, the GM used the purpose of the utility's existence to help create a plan.

Referring to Daphne Utilities' mission statement and purpose of the utility, one cannot sidestep the impact their business has on the environment. To improve the triple bottom line, the GM knew the community's involvement was needed to change the perception of the value of the company. However, there were questions as to how to motivate the community to get involved and be part of the success. The company could not accomplish this on their own.

As was the case in Daphne, AL and most other communities, grease is the main cause of sewer spills. The GM found a problem to solve and a way to connect with the community. In 2005 there was a movement to improve public awareness of the environmental damage that could be caused by not disposing of grease and cooking oil properly.

One of successful projects implemented was the grease recycling program. Daphne Utilities decided to focus on the residential side of sewer spills so as not to compete with grease recycling companies. Also, the commercial side is regulated whereas residential is not. However, progress could only be made if they had help from the community.

Grease recycling stations were placed in convenient locations in the community. Customers could pick up plastic containers at the stations, take them home, put grease in them that is leftover from cooking meals at home, and return the full container to one of the many convenient stations. At the same time, customers could pick up another empty container for future disposal. The wastewater facility would then properly dispose of the grease to ensure that it is not put into the environment or the sewer system.

The General Manager equated pouring grease down a drain to a clogged artery. Healthy eating and exercise can help prevent a clogged artery and costs very little, but once the damage is done, the reactive costs that follow, surgery, medication, time away from work, can be exorbitant. Prevention was one way to reduce sewer spillage costs and educating the community was the key.

The grease recycling program was put in place with the thought that it could ultimately improve community relations and enhance the brand, image, reputation, and triple bottom line of the utility company. The result of implementing a grease recycling program: using the GM's definition of sewer spills, the utility saw a $40 \%$ reduction in sewer spills.

"It is hard to put a dollar figure on an event that does not occur but basically any 'spill' would impact us with clean-up for a crew of about 3-4 persons for almost a full day, miscellaneous equipment including vacuum trucks, work lights, chemicals, soil disposal costs, etc. A relatively small spill that is non-reportable can still easily cost you $\$ 1,000$ per occurrence. Add to this the perception of the public who sees us constantly cleaning up small sewer spills throughout the city and you quickly have a customer base that believes that your sewers are not well maintained and that the city as a whole is 'dirty'. Not exactly a recipe for success for increasing growth in the community!" ("Cease the Grease”, 2014)

\section{Who's at the Table}

For employees and board of directors to only be concerned about the utility's profits is a short-sighted vision. Even though the utility had no competition, the citizens needed to buy in to the value that the water utility was providing to the community. There should be opportunities for the community to become engaged and participate in providing the value for the company. The last point from Urlaub (2013) is to "Invite all the stakeholders to the table to include buy in from all."

Communication was the key to convincing the community to help and the GM had found a story through the grease recycling program that could be translated in different ways to educate all age groups. It would positively impact not only the bottom line, but the triple bottom line. It would also improve the utility's reputation and image.

The story of the spoon was what the general manager told the community. He went into the school system and communities to educate the community. He could take a spoon with him to his presentations to visually show the impact of how just a spoonful of grease could improve their community. The spoon represented one spoonful of 
grease a day for each of the 10,000 households in Daphne which equates to seven 55 gallon drums of grease a month. "He wanted the community to see themselves as part of the story. Make it personal and frame it in the community interests" (McElroy, 2011b).

For the younger children, the GM visited the elementary schools and discussed grease recycling and the byproduct glycerin it produces. Glycerin is a byproduct of converting grease to biodiesel. If you have 100 gallons of oil and convert it to biodiesel, $10-15 \%$ of it will be a glycerin byproduct which can be made into soap. Glycerin soap was colored and molded into animal shapes for students to take home to their parents so they could pass along the story about the grease recycling program.

For teenagers the key points communicated were to show they were helping to save the environment and to communicate the low cost of making biodiesel. As teenagers approach driving age, the cost of gas becomes important to them; therefore, they become more interested in learning about biodiesel options.

As adult homeowners, a residential sewer spill can be messy and costly to clean up. Much of the items in the home are contaminated and cannot be recovered. Not only is the cleanup costly but so is the replacement cost of a house or items in a house, some of which may be considered irreplaceable. It just makes sense to help prevent sewer spills as the adults most likely do most of the cooking in the home.

\section{Concluding Remarks}

Daphne Utilities "create(s) heroes" out of utility customers because they reduced the number of sewer spills caused by grease, which improved the profitability of the utility company. In summary, the grease recycling program allowed Daphne Utilities to accomplish the following:

- To engage and work with the community to solve a problem.

- To create a partnership with the community.

- The partnership created a bond, which improved trust. MC need to add something about importance of trust and bottom line-might want an image of sorts here.

- Trust improved the utility's reputation.

- A good reputation can enhance brand value.

These accomplishments built a strong foundation that put the company in a better position to manage risk and ultimately improve not only profitability, but also the social and environmental bottom line.

Questions for Students (email author for teaching notes)

- List and discuss the management risks associated with a water utility. Read Hargett, Tonya R., Williams, Marcia F. "Wilh. Hilhemsen Shipping Company: moving from SCR tradition to CSR leadership," Corporate Governance, 9.1 (2009): 73-82.

- Research, what other types of grease recycling programs exist and its impact. What are the benefits and costs of starting a grease recycling program?

- How can a grease recycling program impact a triple bottom line?

- Discuss the impact and benefits of corporate social responsibility.

\section{Acknowledgements}

I would like to thank Mr. Rob McElroy, former General Manager with Daphne Utility Company, for providing his time and insight into the development of this case study.

\section{References}

About Daphne Utilities. (n.d.). Retrieved from https://www.daphneutilities.com/about-us/

Cease the Grease. (n.d.). Retrieved from

http://www.daphneutilities.com/environment/cease-the-grease-program-faqs/

Elkington, J. (1994). Towards the Sustainable Corporation: Win-Win-Win Business Strategies for Sustainable Development. California Management Review, 36(2), 90-100. http://dx.doi.org/10.2307/41165746

Kotler, P., \& Keller K. (2011). Marketing Management (14th ed.). Upper Saddle River, New Jersey: Prentice Hall.

McElroy, R. (2011a). Effective Customer Outreach at Little or No Cost [Powerpoint Slides]. Retrieved from http://www.daphneutilities.com/publications/ 
McElroy, R. (2011b). Simple Steps to Building a Great Utility [Powerpoint Slides]. Retrieved from http://www.daphneutilities.com/publications/

McElroy, R. (2011c). Transforming Your Utility from Good to Great [Powerpoint Slides]. Retrieved from http://www.daphneutilities.com/publications/.

Pollution Prevention Project: Sewage Spill Reference. (n.d.). Retrieved from http://ci.carson.ca.us/content/department/eco_dev_service/guide_sewagespill.asp

Preventing Sewage Spills. (n.d). Retrieved from http://hwea.org/education-old/psa/psa_announcement.pdf

United States Census Bureau. (2013). State and County QuickFacts, Daphne, AL [Data file]. Retrieved from http://quickfacts.census.gov/qfd/states/01/0119648.html

Urlaub, J. (2013). The Business Sustainability Handbook: Growth Strategies for a Dying Planet. Lexington, KY: CreateSpace Independent Publishing Platform.

\section{Copyrights}

Copyright for this article is retained by the author(s), with first publication rights granted to the journal.

This is an open-access article distributed under the terms and conditions of the Creative Commons Attribution license (http://creativecommons.org/licenses/by/3.0/). 